\title{
Segmentation, Targeting, dan Positioning Studio Tato di Surabaya dalam Perkembangan Gaya Hidup
}

\author{
Anang Tri Wahyudi \\ Program Studi Desain Komunikasi Visual, Fakultas Seni dan Desain \\ Universitas Kristen Petra \\ Jalan Siwalankerto 121-131 Surabaya \\ E-mail: anang@peter.petra.ac.id
}

\begin{abstract}
Abstrak
Dalam penelitian ini mencoba mengkaji secara mendalam pengaruh gaya hidup terhadap orientasi recipient terhadap seni tato menjadi bernilai komoditi, dan mengeksplorasi sejauh mana Studio Tato yang ada di Surabaya melakukan proses segmentation, targeting, dan positioning dalam mengelola Studio Tato. Penelitian ini menggunakan metode penelitian kualitatif dengan landasan berfikir fenomenologis interpretif, yang berorientasi pada kebenaran yang bersifat subyektif dari informan, yang terdiri dari tattoois dan pengelola Studio Tato yang memiliki pengalaman lebih dari 5 tahun, dan recipient pria dan wanita yang berusia dibawah 30 tahun. Perkembangan gaya hidup pasca modern identik dengan budaya konsumtif, yang mempengaruhi orientasi recipient terhadap tato menjadi sebuah karya seni, media ekspresi, pencarian identitas diri, dan bagian dari asesoris fashion, sehingga tato menjadi karya seni yang memiliki nilai komoditas.Studio Tato yang ada saat ini beberapa sudah memiliki segmen pasar, target pasar, positioning, dan strategi pemasaran yang jelas. Tetapi ada juga beberapa Studio Tato yang tidak menentukan segmen pasar dan target sasarannya, Mereka cenderung mengalir mengikuti situasi dan kondisi pasar. Beberapa faktor yang mempengaruhi kondisi Studio Tato dan pengelolaannya saat ini adalah faktor lingkungan, keterbatasan sumber daya, dan tato sebagai produk seni yang bersifat homogen.
\end{abstract}

Kata kunci: Tato; gaya hidup; segmentation; targeting; positioning.

\begin{abstract}
This study attempts to examine in depth the influence of lifestyle on the orientation of recipients (tattoo users) to the art of tattooing, which is independent of the value of a valuable commodity, and explore the extent to which the process of tattoo studios' segmentation, targeting, and positioning in managing a tattoo studio. This study uses qualitative research methods with interpretive phenomenological foundation of thinking, which is oriented to truth that is subjective to informants, which consists of a tattoo studio tattooist and managers who have more than five years of experience, and the recipient women and men under the age of 30. The development of post-modern lifestyle is synonymous with consumer culture, which affects the orientation of recipients towards tattoos as works of art, a medium of expression, search for identity, and part of fashion accessories, therefore tattoos become works of art that have commodity value. The existing tattoo studios already have market segments, target markets, positioning, and clear marketing strategy, however there are some tattoo studios that do not determine their market segments and target goals. They tend to flow and follow the situation and market conditions. Several factors that affect the condition and management of tattoo studios today are environmental factors, resource constraints, and tattoos as art products that are homogeneous.
\end{abstract}

Keywords: Tattoo; lifestyle; segmentation; targeting; positioning.

\section{Pendahuluan}

Tato mengalami proses dialektika sosial dalam masa perkembangannya, dari budaya tradisional menuju budaya modern. Di masa tradisional tato memiliki fungsi dan makna yang lekat dengan tradisi, baik itu tradisi ritual, sebagai status sosial, penanda perkembangan secara biologis manusia, tanda ketrampilan dan kemampuan seseorang dalam berburu, berperang, dan juga kemampuan lainnya.

Tato bagi masyarakat Dayak tradisional memiliki fungsi dan makna yang sangat sakral, karena pembuatan tato selalu dihubungkan dengan berbagai aspek kebudayaan, diantaranya yaitu peribadatan. Dalam kehidupan sosial tato bagi masyarakat Dayak juga memiliki fungsi dan makna yang 
sangat kuat dalam tatanan kehidupan sosial, seperti tato yang dikenakan oleh perempuan di bagian paha sampai betis dengan ornament tertentu, menunjukkan bahwa perempuan tersebut dari golongan bangsawan.

Tato yang dikenakan oleh seorang prajurit yang dianggap sudah pernah memenggal kepala musuhnya (mengayau), akan dikenali lewat tanda tato pada tubuhnya berupa garis-garis yang halus dan tajam pada kedua tangannya. Di Mentawai tato juga memiliki fungsi dan makna yang hampir sama dengan tato di Dayak, yaitu dikaitkan dengan kepercayaan, sebagai identitas dalam tatanan sosial berupa keanggotaan dari suku tertentu. Fungsi lain tato Mentawai yaitu sebagai simbol kemahiran atau ketrampilan secara skill dari seseorang, misalnya tato gambar binatang biasa dikenakan oleh seseorang yang ahli berburu binatang.

Di masa modern eksistensi tato bergeser secara fungsi dan pemaknaannya, tato berfungsi sebagai media ekspresi diri, media pencarian identitas, sebagai tanda keberanian, dan pendukung penampilan atau bagian dari asesoris gaya hidup. Di dalam periode tahun 1960 sampai tahun 1980-an tato sangat dekat dengan kehidupan yang sangat keras dan identik dengan kriminalitas, karena dalam periode itu tato banyak dikenakan oleh para narapidana dan juga para preman. Sehingga image tato di tengah masyarakat saat itu sangat negatif dan ditakuti, apalagi pada masa 1983-1984 terjadi peristiwa yang terkenal denga istilah "petrus" yaitu pembunuhan misterius terhadap orang-orang bertato yang dianggap sebagai kriminal (Marianto dan Barry, 2002: 12-13).

Di masa kebebasan berdemokrasi dan keterbukaan informasi secara global, telah membentuk budaya popular yang memandang tato saat ini sebagai bagian dari kebutuhan gaya hidup. Tato tidak lagi identik dengan kriminalitas dan kaum pria, tetapi saat ini tato juga disenangi dan dipakai oleh kaum wanita, sebagai bagian dari penunjang penampilan, media bersenang-senang, ekspresi diri, dan juga dipandang sebagai karya seni yang memiliki nilai estetik.

Dengan berkembangnya budaya konsumtif dan keinginan masyarakat yang besar terhadap tato, menjadikan tato sebagai produk seni yang bersifat mass production. Tato tidak lagi sebagai bentuk kebudayaan yang bebas nilai, tetapi sebagai produk seni yang memiliki nilai komoditas, yang memiliki nilai tukar berupa uang bagi orang yang menginginkan tato di tubuhnya. Dengan banyaknya permintaan masyarakat terhadap tato memicu munculnya berbagai studio tato di berbagai tempat, sebagai bentuk usaha untuk melayani dan memenuhi keinginan masyarakat terhadap tato.

Sebuah studio tato membutuhkan sistem manajemen yang baik di tengah persaingan banyaknya studio tato yang ada, salah satunya adalah membangun strategi pemasaran yang tentunya dimulai dengan melakukan proses segmentation, targeting, dan positioning yang dilakukan untuk mengenal karakter dan segmen pasar yang ingin dilayani.

Berdasarkan pada eksistensi tato dan perkembangan tato yang mengalami proses adaptasi dan pergeseran fungsi dan maknanya, serta pengaruh perkembangan gaya hidup saat ini yang cenderung kepada budaya konsumtif dan budaya popular, memposisikan tato sebagai produk seni yang memiliki nilai komoditi. Hal ini menimbulkan pertanyaan bagaimanakah perkembangan gaya hidup telah mempengaruhi orientasi masyarakat terhadap eksistensi tato, dan sejauh mana studio tato yang ada mengelola dan menentukan segmentation, targeting, dan positioningnya?

\section{Metode Penelitian}

Penelitian ini bersifat kualitatif dengan landasan berfikir fenomenologis interpretif, yang berorientasi pada tingkat kebenaran yang bersifat subyektif dari informan sebagai sumber penelitian. Menurut Alfred Schutz pengalaman yang bersifat subyektif selalu bersentuhan atau berinteraksi langsung dengan obyek yang diamatinya (dalam Norman \& Yvonna, 2009: 337). Dalam hal ini subyek penelitian telah ditentukan sesuai dengan tujuan penelitian,yaitu 4 orang tattoois, 4 orang pengelola studio tato, dan 4 orang recipient yang dianggap mampu memberikan informasi yang valid dan memiliki latar belakang serta mewakili populasinya masing-masing.

\section{Pembahasan}

Dalam penelitian terhadap permasalahan tato ini didasarkan pada sumber informasi yang telah ditentukan, yaitu informan tukang tato (tattoois), pengguna tato (recipient), dan pengelola atau pemilik Studio Tato, hal ini bertujuan untuk memperoleh informasi yang valid dan dapat menginformasikan kondisi dan situasi yang memiliki nilai kebenaran sesuai dengan kenyataan.

Dari hasil analisis dalam penelitian menunjukkan kecenderungan terbanyak dari informan yang dijadikan sumber informasi, menyatakan bahwa alasan recipient menggunakan tato adalah ber- 
awal dari perasaan senang terhadap tato, tato sebagai karya seni, tato sebagai media ekspresi, tato dapat menunjang penampilan, dan tato dapat membangun kepercayaan diri masing-masing informan pengguna tato.

Jadi orientasi recipient dalam memutuskan untuk mengenakan tato adalah sebagai media bersenang-senang, mengapresiasi sebagai produk karya seni, dan sebagai pendukung penampilan untuk mengekspresikan kepribadiannya. Sehingga bisa dikatakan kecenderungan ini sebagai bagian dari pola gaya hidup yang mengarah pada budaya popular, yang setiap orang mengkonsumsi segala sesuatu berorientasi sebagai wujud bersenangsenang dan menampilkan identitas pribadinya.

Ada beberapa hal yang membedakan recipient dalam menginterpretasikan keberadaan tato yaitu yang memiliki pandangan bahwa tato harus memiliki makna dan tujuan yang jelas bagi penggunanya, dan ada juga yang menganggap tato sebatas karya seni yang memiliki nilai estetika dan sebagai media ekspresi semata. Seperti tato milik informan MV seperti Gambar 1,

Tato milik informan MV di atas memiliki bentuk leak yang merupakan representasi dari apresiasi dan kecintaannya terhadap konsep tradisi, sehingga dengan tato dapat diketahui bahwa si pemilik tato memiliki konsep dan pemahaman tersendiri terhadap seni tato.

Tato bergambar bulu merak di tubuh informan OD juga memiliki arti dan makna tersendiri yaitu sebagai simbol lucky atau keberuntungan bagi penggunanya.

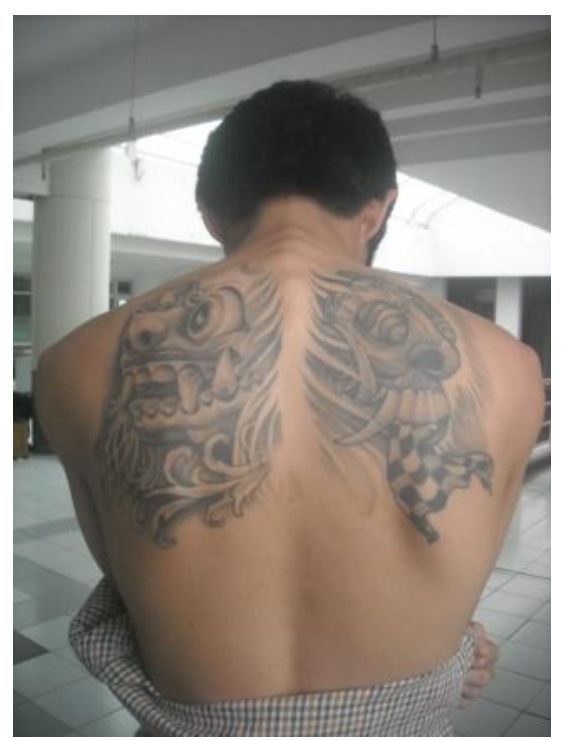

Gambar 1. Tato berbentuk leak di punggung informan MV (21 Tahun)

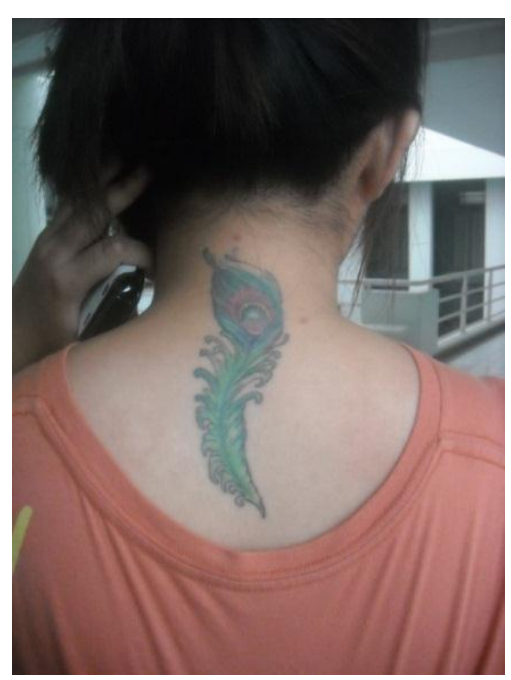

Gambar 2. Tato bergambar bulu merak di tubuh informan OD (21 Tahun)

Bagi recipient lainnya tato dikenakannya sebatas sebagai bentuk ekspresi diri dan kecintaannya terhadap bentuk artistik dan keindahan visualnya tanpa memperhatikan arti dan makna secara mendalam. Pengguna tato seperti ini biasanya berorientasi pada keunikan dan estetika secara visual dari berbagai gaya yang ada pada seni tato.

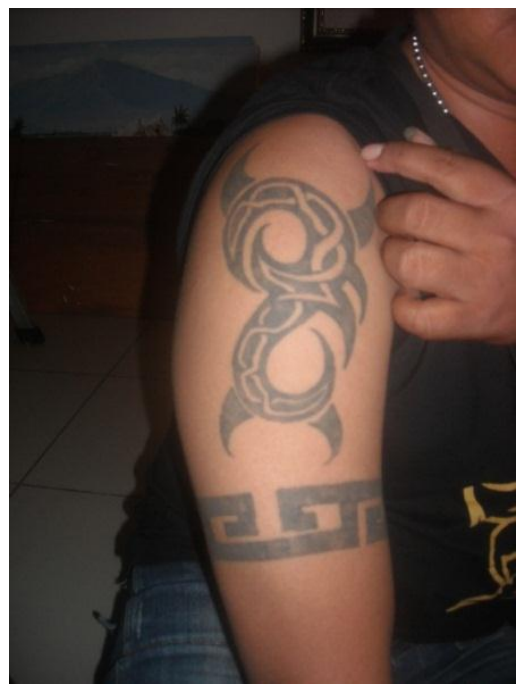

Gambar 3 Tato bergaya tribal di tubuh informan CA (29 Tahun)

Tato bergaya tribal di lengan informan CA adalah tato yang murni mengedepankan kecintaan dan apresiasi penggunanya terhadap keindahan dan nilai artistik dari motif tribal yang berupa hiasan garis hitam tebal yang memiliki karakter dan gaya ornamental. saat ditanya berkaitan dengan alasan memilih motif visual dan alasan bertato informan CA mengatakan sebatas senang dengan motif tribal dan dengan bertato dia merasa lebih percaya diri. Orientasi dari setiap recipient dalam mengenakan tato di tubuhnya memiliki alasan dan latar 
belakang beragam, hal ini dipengaruhi oleh latar belakang lingkungan sosial maupun pendidikan recipient. Tato sebagai media ekspresi dan bentuk karya seni yang berfungsi sebagai pendukung penampilan bagi penggunanya, mampu membangun kepercayaan diri dan identitas recipient sebagai bagian dari masyarakat secara luas.

Studio tato sebagai salah satu bentuk usaha atau bisnis yang bergerak dibidang pelayanan jasa pembuatan tato sudah semestinya memiliki tujuan yang pasti, dan memiliki strategi dalam menjalankan usahanya tersebut. Salah satu strategi yang umumnya dilakukan dalam menjalankan sebuah usaha yaitu strategi pemasaran. Mengetahui proses segmentation, targeting, dan positioning membantu dalam mengukur sejauh mana efektivitas dan efisiensi sebuah strategi untuk mencapai hasil yang dituju.

Segmentation merupakan kegiatan membagi-bagi pasar dari yang bersifat heterogen menjadi bersifat homogen, dimana pasar dikelompokkan sesuai dengan pasar yang memiliki karakter, kebutuhan dan keinginan yang sama terhadap suatu produk. Selanjutnya target atau sasaran yang dituju dalam pemasaran dilakukan setelah berhasil mengidentifikasi segmen pasar yang dituju, dengan memilih target sasaran yang sesuai dengan kondisi studio Tato dan memilih target yang potensial menjadi target pasarnya. maka langkah berikutnya yang bisa dilakukan adalah menentukan positioning dari produk yang akan ditawarkan. Usaha untuk menarik perhatian dan menanamkan nilai-nilai suatu produk ataupun brand perusahaan kepada konsumen yaitu dengan cara membangun suatu kepercayaan dan loyalitas konsumen untuk tetap setia pada satu produk yang dipasarkan.

Dari hasil analisis dalam penelitian ini secara manajerial menunjukkan bahwa semua studio tato yang dijadikan obyek penelitian dan juga informasi dari informan pengelola studio tato diketahui bahwa dalam pengelolaan studio tato dan usaha jasa tatonya masing-masing informan ada yang sudah melakukan proses segmentation dan targeting, dan ada yang belum. Hal ini dipengaruhi oleh beberapa faktor diantaranya adalah keterbatasan sumber daya dan faktor homogenitas produk yaitu tato.

Dalam membangun citra di benak recipient atau membangun positioning, masing-masing informan pengelola Studio Tato dan juga informan tattoois memiliki kecenderungan yang hampir sama, yaitu melalui bentuk pelayanan, meyakinkan kepada recipient akan tato yang aman dan higienis, dan jasa konsultasi sebelum melakukan proses pem- buatan tato. Tetapi ada beberapa hal yang berbeda yang dimiliki oleh masing-masing informan, diantaranya yaitu informan BT dengan Studio Tato "Alliens" mengedepankan pengalaman dan prestasi tattooisnya. Informan GT dengan Studio Tato "Lost13Angels" memberikan bonus kaos kepada recipient yang menghabiskan dana lebih dari Rp. 500.000. Informan AW dengan Studio Tato AW memberikan pelayanan desain gratis dan harga yang bisa menyesuaikan. Serta informan IS dengan jasa Tato kelilingnya membangun brand dan positioning kepada recipientnya dengan proses pembuatan tato yang relatif cepat dan harga serta bentuk pembayaran yang fleksibel.

Dalam penelitian ini dapat diketahui proses segmentation, targeting, dan positioning masingmasing Studio Tato sebagai berikut:

1. Studio Tato "Alliens": segmen pasarnya adalah menengah ke atas, menururt informan BT sebagai pengelola, orang yang datang di mall adalah orang-orang yang potensial menjadi target sasarannya, karena mereka memiliki banyak uang untuk berbelanja dan memiliki karakter yang mengutamakan kesenangan dan penampilan melalui barang-barang yang dibelinya. Positioning yang dibangun yaitu dengan mengutamakan pelayanan, fasilitas yang memadai, aman dan higienis, serta kualitas gambar dan tattoois yang berpengalaman serta berprestasi.

2. Studio Tato "Lost13Angels": Segmen pasarnya adalah mahasiswa dan kalangan anak muda, yang menurut informan GT sebagai pemilik sekaligus pengelola, mahasiswa dan kalangan anak muda Surabaya sangat potensial menjadi target sasaran karena mereka dianggap gaul dan sangat menyenangi tato sebagai media ekspresi dan pencarian jati diri mereka. Positioning yang dibangun oleh informan GT pada Studio Tatonya yaitu dengan cara memberikan pelayanan yang maksimal, fasilitas yang memadai, aman dan higienis, serta pemberian bonus berupa kaos bagi recipient yang menghabiskan dana untuk tato lebih dari Rp.500.000.

3. Studio Tato AW: Dalam mengelola Studio Tatonya, informan AW sebagai pemilik sekaligus pengelola belum melakukan proses segmentation dan targeting, dia menjalankan dan mengelola studionya dengan prinsip mengalir mengikuti situasi dan kondisi pasar. Tetapi karena keberadaan sumber daya yang terbatas dan sifat produk tato sebagai produk yang homogen, pasar yang dilayaninya banyak dari kalangan menengah ke bawah, diantaranya adalah teman-teman informan AW, masyarakat kampung di sekitar lokasi Studio Tato 
AW,dan beberapa orang yang mengenal informan AW. Positioning yang dibangun oleh informan AW pada Studio Tato AW yaitu pelayanan yang maksimal, proses tato yang aman dan higienis, dan jasa konsultasi serta desain tato gratis, sedangkan harga bisa menyesuaikan kemampuan recipient.

4. Studio Tato keliling IS: Dalam menjalankan usaha tato kelilingnya, informan IS banyak melayani recipient dari kalangan menengah ke bawah. Seperti pengamen, kuli bangunan dan kuli pelabuhan, orang-orang yang ditemuinya di warung-warung, lingkungan lokalisasi, serta teman-teman informan IS sendiri. Dalam pelaksanaannya informan IS tidak melakukan proses segmentation dan targeting, tetapi mengalir mengikuti situasi dan kondisi pasar seperti halnya informan AW. Hal ini dikarenakan adanya keterbatasan sumber daya dan sifat tato sebagai produk yang homogen. Sehingga kalangan yang memungkinkan untuk dilayani yaitu kalangan menengah ke bawah yang memiliki karakteristik dan keinginan yang relatif sama, yaitu dengan dana yang terbatas tetapi menginginkan dirinya memiliki tato di tubuhnya sebagai bentuk ekspresi diri, pendukung penampilan dan menambah kepercayaan diri. Positioning yang dibangun oleh informan IS pada jasa tato kelilingnya yaitu dengan cara memberikan jasa tato dengan harga yang relatif murah dan fleksibel serta pengerjaan tato yang relatif cepat, sehingga recipient tidak terlalu bosan dan bisa segera melanjutkan aktivitasnya.

\section{Kesimpulan}

Banyak peminat tato pada saat ini yang menganggap tato sebagai bentuk karya seni yang memiliki nilai estetika, tato sebagai media ekspresi diri, tato sebagai penunjang penampilan atau fashion, dan tato dapat menambah kepercayaan diri bagi penggunanya.

Gaya tato yang dianggap bertahan secara stabil hingga saat ini yaitu gaya tato oriental dan gaya tato tribal. sedangkan gaya tato yang sedang trendy diantaranya adalah gaya realis 3 dimensi, new school, old school, batikan, dan black \& grey.

Banyak Studio Tato yang berdiri baik itu berupa home studio, studio di ruang publik seperti di mall dan di salon-salon kecantikan, tidak membuat khawatir pemilik dan pengelola Studio Tato akan adanya persaingan. Mereka merasa senang dengan banyaknya Studio Tato, sehingga eksistensi tato semakin diterima dan dikenal di masyarakat. Menurut semua informan pengelola Studio Tato dan tattoois, usaha di bidang tato dirasakan cukup menjanjikan, memiliki prospek yang baik, dan dari segi penghasilan dirasa cukup memadai bagi pengelola Studio Tato dan tattooisnya.

Bentuk usaha pelayanan jasa tato saat ini tidak hanya berupa home studio atau Studio Tato yang permanen lainnya, tetapi ada yang melakukannya dengan cara keliling dan pelayanan jasa tato panggilan.

Dari informasi pengelola Studio Tato yang ada saat ini ditemukan bahwa belum adanya kesadaran secara manajerial untuk membuat strategi pemasaran yang spesifik, termasuk tentang proses segmentation, targeting, dan positioning. Yang terjadi adalah diantara Studio Tato yang dijadikan obyek penelitian diantaranya sudah memiliki segmen pasar tersendiri, tetapi segmen tersebut terbentuk oleh karena adanya faktor lingkungan, keterbatasan sumber daya, dan sifat tato sebagai produk yang homogen.

Studio Tato yang terdaftar dalam Association Subculture (ASC) memiliki standarisasi dalam operasional, diantaranya yaitu ketentuan tentang batas usia recipient, yaitu minimal 17 Tahun ke atas. Sedangkan Studio Tato yang tidak terdaftar dalam ASC cenderung bebas tanpa ketentuan yang berlaku dalam melayani recipient.

\section{Daftar Pustaka}

Chaney, David, 2011. Lifestyle, Sebuah Pengantar Komprehensif. Jalasutra, Yogyakrta.

Denzin, Norman K., \& Lincoln, Yvonna S. 2009. Handbook of Qualitative Research. Pustaka Pelajar, Yogyakarta.

Handoko, Cons.Tri, 2007, Fungsi dan Makna Tanda pada Tato di Tubuh para Narapidana dan Tahanan di Lembaga Pemasyarakatan Klas II A Yogyakarta, Yogyakarta, Sekolah Pasca Sarjana UGM.

Juliastuti, Nuraini \& Antariksa (Editor), 2000. Remaja, Gaya, Selera. Newletters KUNCI, No. 6-7 Mei - Juni 2000, Yogyakarta

Kotler, Philip, Hermawan Kartajaya, \& Iwan Setiawan, 2010, Marketing 3.0. Erlangga, Jakarta

Marianto, M. Dwi \& Syamsul Barry,2000. Tato. Lembaga Penelitian Institut Seni Indonesia Yogyakarta, Yogyakarta

Miller, Jean-Chris, 1997, The Body Art Book, Berkley Books, New York

Moleong, Lexy J., 2011. Metodologi Penelitian Kualitatif. PT Remaja Rosdakarya, Bandung

Olong, Abdul Kadir, 2006. Tatto, LKis Plangi Aksara, Yogyakarta. 
Puspita, R.R Early Dinda, 2006. Fenomena Tren Tato dan Pergeseran makna Seni Tato Ditinjau dari Teori Postmodern dan Teori Semiotik Pierce. FIBUI, Jakarta.

Swastha, Basa DH., \& Irawan, 2008. Manajemen Pemasaran Modern. Liberty, Yogyakarta.
Sugiyono, 2007. Metode Penelitian Kuantitatif, Kualitatif, dan R\&D. ALFABETA, Bandung. Usmara A. \& Budiningsih B. (editor), 2003. Marketing Classics. Amara Books, Yogyakarta. Skindeep, No 88, September 2002. 